\title{
CD226 Antigen
}

National Cancer Institute

\section{Source}

National Cancer Institute. CD226 Antigen. NCI Thesaurus. Code C104067.

CD226 antigen (336 aa, $38 \mathrm{kDa}$ ) is encoded by the human CD226 gene. This protein is involved in cellular adhesion of platelets and megakaryocytic cells and megakaryocytic cell maturation. 